\title{
In the Cracks
}

\author{
Eva M Mathews ${ }^{1}$ (ID
}

Received: 2 September 2021 / Accepted: 6 January 2022 / Published online: 27 January 2022

(C) Academic Psychiatry 2022

Ring the bells that still can ring / Forget your perfect offering / There is a crack, a crack in everything / That's how the light gets in.

-Leonard Cohen

How do we grieve our patients while we also take care of our families, of others and feed the hungry EMR? In the cracks, it seems. It was $1 \mathrm{am}$. I woke up with a dry throat and tightness in my chest. Was it the start of a virus? No, I knew this - fear and sadness, trying to find their way out. I had lost two patients in the span of two weeks, Sylvia and Anna.

At lunchtime, I found my nurse's door cracked open,

"I have some sad news." I faltered, "Do you want to hear that now, or at the end of the day?"

What an opening. We worked with Sylvia together for three years through visits and abrupt phone calls, outbursts, and tears.

"Tell me now. It's ok." I'm not sure my introduction left a choice.

"Sylvia died by suicide. I think it was suicide. She died by an overdose." I felt like I had been hit in the chest and now I was harming my nurse, too. I told her the limited and heartbreaking details I knew. We both saw how much Sylvia lived to get her young son back from foster care. Maybe something happened with the custody. I apologized to my nurse for telling her. She thanked me for telling her. It was a strange dance of mourning.

Note: The patients described here have pseudonyms with details disguised.

Eva M Mathews

Ematt6@1suhsc.edu

1 Louisiana State University - Our Lady of the Lake, Baton Rouge, LA, USA
This was the second patient suicide in my career; the first patient I lost, Anna, died just two weeks prior. These deaths created a wound both emotionally and in my identity as a doctor. I saw the rest of my patients for the day. With each one, I smoothed a therapeutic mask over my face on the walk to the waiting room. I hated hiding this pain. It felt like lying, but I couldn't burden my patients with this.

I was able to leave work early and pick up my son from school. His running hug nearly knocked me to the ground and his constant happy chatter about monster trucks, friends, and deep thoughts on playground shenanigans kept me occupied. I only felt the sadness creeping in during silence.

I lost my good friend and colleague the year before to suicide and now my two patients. I did not see it coming with any of them. People often said this. The literature said this. It didn't help. On Mother's Day, I spoke in code to my motherin-law while the kids ate chocolate cake, their faces messy and delighted.

"I'm sorry," she told me, "I've found that when people really are determined, you just can't stop them." This is all we got to say, but it helped shine light into the crack. A little.

The next morning, I met with a group of my colleagues who are also my mentors. I asked how they have dealt with these losses. Their words were kind and simple. They recounted stories of patients so resolute to end their lives they went to extraordinary means. We supported each other through our stories. By letting ourselves feel pain, we reinforced the fact that we are not gods, and the pain reduced just a fraction. There are limits to what we can control.

"You did the best you could with what you knew at the time. Why would you do anything differently?"

That afternoon, I was furiously learning about the connection between essential tremor, addiction, and D3 receptors for upcoming grand rounds. Then, I got a note and a wave of nausea hit me. Anna's brother wanted to speak with me. I was filled with fear and grief again. I thought, I did everything I could, but he was enduring a tragic, unexpected loss. Would 
he see me as the cause of his family's suffering? Over the phone, we made plans to meet the following week. He told me he didn't blame me, but I couldn't stop that thought from surfacing.

The day of our meeting, I pored over every note I wrote about Anna, looking for something I might have missed. She only revealed parts of her suffering to me. Anna's brother was composed and kind. We shared what we knew about Anna. He showed me her suicide note. In it, Anna said that her psychiatrist and therapist were amazing people. I couldn't process that. I was stuck in my own cycle of torment and professional guilt. Psychiatrists are supposed to prevent suicide and I didn't do that.

Anna's brother told me that Anna had written multiple drafts of the suicide note. Yet, she had a full tank of gas, groceries, and plans for the next week. I described the cycle of grief after the suicide of a loved one. I drew on what I had been taught in residency, what I have learned from my patients, and from my own experiences. I told him that he would go through ups and downs over time. Grief is a series of waves, not a straight path to acceptance. Grief is a wound that will never go away, but sometimes scars tell our most important stories. I told him he couldn't have prevented Anna's death. It was not his fault.

He told me the same thing. It helped.

When he left, I took some time to close my eyes, gather my thoughts, and breathe. The loss of someone to suicide can feel like there is no more work to be done. It is final. But, the rest of us live on in great anguish and when we find people who will help us shine light into the cracks, slowly, we begin to heal.

\section{Declarations}

Disclosures The author states that there is no conflict of interest.

Publisher's Note Springer Nature remains neutral with regard to jurisdictional claims in published maps and institutional affiliations. 